\title{
Bibliographic review of articles on pedagogical practice of environmental education in schools
}

\author{
Pitt de Mello ${ }^{1}$, Rebeca C.A. Fernandes 2
}

1 - Graduate Program of Teachingand History of Earth Sciences, P0Box 6152, 13083-855 Campinas, SP, Brazil. E-mails: pitt1mel@gmail.com

2 - Graduate Program of Teachingand History of Earth Sciences, P0Box 6152, 13083-855 Campinas, SP, Brazil_E-mails: rebeca_chiacchio@hotmall.com

Abstract:This article aims to identify pedagogical practices in the area of Environmental Education (EA) developed in Elementary Schools. We have carried out a bibliographical research of articles published in the last five years in national and international journals. Eight journals were consulted, one of them referring to Geosciences Teaching, four of them referring to Science Teaching and three specifically about Environmental Education taking all the numbers published between 2013 and 2017. In those journals, thirteen articles were selected that presented some relation to our research focus, and these were described and characterized in relation to the School Level, Thematic Area, Methodological Approach and Macro tendency of Environmental Education. In the set of papers analyzed, there was a predominance of papers focused on the Elementary Education Level, for the Thematic Area of Environmental Education and Pragmatic macro tendency. In relation to the Methodological Approach, we identified works on environmental conceptions, proposing seminars on sustainability, analysis of pedagogical practices in Environmental Education, among others. We have identified that although there are many studies focusing on Environmental Education in schools, none of them are concerned with the proposals of Government Organizations for Environmental Education in Environmental Education, the focus of our Master's research, which justifies its development.

\section{Manuscript:}

Received: Quadrennial Conference of the International Geoscience Education Organization Accepted: 10/08/2018

Citation: Mello P., Fernandes R.C.A.. 2018. Bibliographic review of articles on pedagogical practice of environmental education in schools. Terræ Didatica, 14(3):304-312. URL: http:// www.ige.unicamp.br/terraedidatica/.

Keywords: Environmental Education; Pedagogical practices; Elementary School

Thematic Line : Environmental Education, Education for Sustainability, Geoscience

\section{Introduction}

Nowadays we live a deception concerning to economic progress and its consequences for such social differences and environmental degradation generated in different regions of the Globe. Departing from this thought, the environmentalist movement starts to trace its way and strengthen all around the world, either through civil society or Public Organizations. International conferences such as Stockholm (1972), Tbilisi (1977) and Rio de Janeiro (1992) were symbols for the environmental movement and they have guided the educational public policies as a possibility of education that seeks for a new way of society thinking and a new life project for the collectivity.

In the academic aspect, the Environmental Education has been consolidating in Brazil as knowledge field with the contribution of academic production, which begins in the 1980s and expands from the 1990s (Megid Neto 2009). In politic area, according to Rink (2009), the addition of Environmental Education to public policies and social movements shows us the increasing appreciation towards environmental crises.

Thus, in the field of practices, many countries incorporated the ecological discourse on their governance guidelines as well as many ideas of environmental education were incorporated to the educational system of the country (at least as a set forth in the law), even though the discussions and reflections about the real meaning and importance of environmental education were not assimilated by most of the educators. According to Bagnolo (2010), there is an abysm between what the university produces theoretically and what is effectively practiced in Brazilian schools.

Therefore, Environmental Education is liable to be treated in a different ways by different actors being able to transit among social, political and economic sectors that generate a big range of interpretations, which may match and diverge. In these areas theoretically, some authors characterize the different conceptions or tendencies of Environmental Education, for example Amaral (2003). 
Brügger (1994), Lima (2005), among others. We will rely our work on Layrargues and Lima (2014) who point out three macro tendencies on Environmental Education: conservationist, pragmatic and critical.

According to the authors, the conservationist macro tendency connects to ecology principles enhancing the affective dimension towards nature and the behavioral change of the individual towards the environment. This macro tendency, according to the authors, is based on the litigation for cultural change that relativize the anthropocentrism, and for being distant from social and political dynamics and their respective conflicts, presents limited potential to add up to forces which struggle for social transformation.

According to Layrargues \& Lima (2014), the pragmatic macro tendency covers education trends for Education for Sustainable Development and for Sustainable Consume and is, in the author's point of view, the expression of environmentalism of results, contemporary pragmatism and market environmentalism. According to the authors, this macro tendency ends up converging with the idea of Sustainable Consume which also relates with other expressions of dynamic conservatism which operates superficial, technological and behavioral changes.

The critical macro tendency supports the critical review of the elements that lead to human being domination and mechanisms of Capital accumulation, seeking for political confrontation about the inequalities, socio-environmental injustice. According to the authors, in this macro tendency we try to contextualize and politicize the environmental debate, problematize the inconsistency of development and society models through a strong sociological and political bias that introduces in the debate key concepts as citizenship, democracy, participation, emancipation, conflict, environmental justice and social transformation (Layrargues \& Lima 2014).

Against this diversity of trends in the studies about Environmental Education, it is necessary to analyze and reveal the ideas applied in the pedagogical practices developed in schools in order to contribute for the construction of practical and theoretical framework that unveil new ways, strategies, and other ways of thinking and interpret Environmental Education. According to Leff (2012, p.17) "it is required a new vision of human development that reintegrates nature values and potentials, social externalities, subjugated knowledge and the complexity of the world".

The challenge is to develop a kind of Environmental Education that is critical and innovative, reflecting political action directed to social transformation. A critical Environmental Education with the role to struggle for a counter-hegemonic path that integrates the problems of the populations most affected with socio-environmental problems.

In view of these considerations, we will aim to connect the concerns with pedagogical practices developed in schools to the studies of academic production in Environmental Education area.

According to Megid Neto (1999), the academic research about EE in Brazil has grown significantly in recent years, mainly after 1990 . According to Fracalanza et al (2005), it was estimated at the time that nearly 800 investigative works (dissertations and theses) had been produced in Brazil up to 2005. Four years later Megid Neto (2009) estimated a production of nearly 2800 works.

For the increase of production, we highlight the importance of carrying out studies that make it possible to follow the trajectory of this area, to make critical evaluations, propose new research possibilities (Sposito, 2002), as well as to point out trends and gaps in the production as it is made in the studies of bibliographic revision or State of Art (Megid Neto, 1999).

Aiming to identify educational pedagogical practices in Environmental Education and to analyze how $\mathrm{EE}$ has been worked on school pedagogical projects we have carried out a bibliographic review with the objective of identifying what is researched about pedagogical practices in Environment Education in Elementary Schools. The present article which presents a cut of a broader research, will seek to initiate the debate on these questions that will be deepened during the masters research.

\section{Objectives and Methodology}

We aim to identify articles published about pedagogical practices in Environmental Education in Elementary School in national and international scope and to discuss about characteristics and general trends of these articles. For this purpose we carried out a bibliographic review from surveying articles about pedagogical practices o EE published in national and international scientific journals in the last five years (2013 to 2017). 
The journals consulted are widely circulated and representative in the area of the Postgraduate Program which we are part of (Geoscience Education, Sciences Education) and in the specific area of this research (Environmental Education). The consultation was conducted directly on the websites of the electronic journals as well as in the Library of the Geosciences Institute of Universidade Estadual de Campinas. The scientific journals consulted were:

- Journal of Geoscience Education: volume 61-2013 to volume 65 - 2017;

- Enseñanza de las Ciencias: volume 08- 2013 to volume 35 - 2017;

- Pesquisa em Educação Ambiental: volume 08 2013 to volume 12 - 2017;

- Revista Eletrônica do Mestrado em Educação Ambiental (Remea): volume 30 - 2013 to volume 34 - 2017;

- Ambiente e Sociedade: volume 13 - 2013 to volume 20 - 2017;

- Ciência e Educação: volume 19-2013 to volume 23 - 2017;

- Investigação em Ensino de Ciências: volume 18 2103 to volume $22-2017$;

- Ensaio Pesquisa em Educação em Ciências: volume 15 - 2013 to volume 19 - 2017.

The search consisted of reading the titles and summaries of all the volumes of the periodicals consulted in the selected period (2013 to 1017) and the selection of those works that presented greater relation with the focus of our research for full reading and description.

After complete reading the articles that represent some relation with the subject of our research (School Level: Elementary or equivalent; Thematic area: Geosciences, Science Education, Environmental education; Methodological Approach: description of school pedagogical practices; Macro tendency of Environmental Education: critical), we tried to describe them briefly pointing out the main characteristics and trends related to School Level. Thematic Area, Methodological Approach, Macro Tendency of EE.

\section{Results}

We identified in the periodicals consulted 13 articles on the broader thematic of our research.
However, out of the thirteen articles selected for a first reading, only five specifically dealt with EE pedagogical practices in Elementary School and middle school. We did not identify papers relevant to this theme in the following volumes consulted in the journals: Ambiente e Sociedade; Ciência e Educação; Investigações em Ensino de Ciências; Ensaio Pesquisa em Educação em Ciências. Here are the references of the 13 selected articles:

We will present a brief description of the selected articles, aiming to discuss the subjects researched, the documents consulted and the results obtained by the authors.

The articles referring to the Journal of Geoscience Education depart from the concept of sustainability as the guiding principle to develop pedagogical projects in schools and in teacher training, which take into account the interdisciplinarity to work on topics such as: Environmental degradation, loss of biodiversity, climate change, consumerism, scientific and geoscientific literacy. It is important to point out that during the search in this journal, the term "Environmental Education" was not detected in the works, the term more commonly applied in articles published in the Journal of Geoscience Education is: Education for Sustainable Development.

In the article "Sustainability: why are language and sustainability ethics important in geoscience classes?” (Metzger \& Curren 2017) [Ref.1], the authors discuss the issue of sustainability based on ethics and its challenges, conflicts of values in various social contexts in the dialog among them as a possible solution for environmental problems. The study compiles approaches and selects teaching materials to help geoscience educators to connect the concepts and principles to be worked in the classroom and concludes with an appeal for greater interdisciplinary dialogue among the various professionals to include the concepts of ethics and sustainability in the discussion.

The second article "Interdisciplinary Science Integrated in the Critical Zone as a fundamental curriculum to approach Environmental Sustainability issues" (White et al. 2017) [Ref.2], is based on the concept of Critical Zone of the Earth, that involves interactions between rock, soil water and air, as a proposal of a holistic system to develop the teaching of Terrestrial and Environmental Science to achieve the final concept of environmental sustainability.

\begin{tabular}{c|c|c|c|c|c}
\hline (C) Terrae Didat. & Campinas, SP & v.14 & n.3 & $304-312$ & jul./set. 2018 \\
\hline
\end{tabular}


Tabela 1. References of the selected articles.

\section{JOURNAL OF GEOSCIENCE EDUCATION}

\begin{tabular}{l|l}
\hline [Ref.1] & $\begin{array}{l}\text { Sustainability: Why the Language and Ethics of Sustainability Matter in the Geoscience } \\
\text { Classroom Ellen P. Metzger e Randall R. Curren, v. 65, n. 2, 2017. }\end{array}$ \\
\hline [Ref.2] & $\begin{array}{l}\text { Integrated Interdisciplinary Science of the Critical Zone as a Foundational Curriculum for } \\
\text { Addressing Issues of Environmental Sustainability. Timothy White, Adam Wymore, Ashlee } \\
\text { Dere, Adam Hoffman, James Washburne, e Martha Conklin, v. 65, n. 2, 2017. }\end{array}$ \\
\hline [Ref.3] & $\begin{array}{l}\text { How Does Adding an Emphasis on Socio scientific Issues Influence Student Attitudes } \\
\text { about Science, Its Relevance, and Their Interpretations of Sustainability? Michael A. } \\
\text { Pelch an David A. McConnell, v. 65, n. 2, 2017. }\end{array}$ \\
\hline [Ref.4] & $\begin{array}{l}\text { The Geology and Sociology of Consumption: Team-Teaching Sustainability in an Interdis- } \\
\text { ciplinary First-Year Seminar. Emily O. Walsh e Erin Calhoun Davis, v. 65, n. 2, 2017. }\end{array}$ \\
\hline
\end{tabular}

\section{ENSEÑANZA DE LAS CIENCIAS}

\begin{tabular}{l|l}
\hline [Ref.5] & $\begin{array}{l}\text { Concepciones sobre Educación Ambiental y Desarrollo Profesional del profesorado de } \\
\text { ciencias experimentales en formación. Diego Cardona Restrepo, v. 31, n. 2, 2013. }\end{array}$ \\
\hline [Ref.6] & $\begin{array}{l}\text { Identificación y caracterización de las concepciones de medio de un grupo de profesionales } \\
\text { de la educación ambiental. Genina Calafell Subirà; Josep Bonil Gargallo, v. 32, n. 3, } 2014 .\end{array}$ \\
\hline [Ref.7] & $\begin{array}{l}\text { Caracterización de las concepciones de complejidad de un grupo de investigadores de la } \\
\text { educación ambiental. Genina Calafell Subirà; Neus Banqué Martinez, v. 35, n. 1, 2017. }\end{array}$ \\
\hline
\end{tabular}
RESEARCH IN ENVIRONMENTAL EDUCATION

\begin{tabular}{l|l}
\hline [Ref.8] & $\begin{array}{l}\text { A Prática de Educação Ambiental no Âmbito do Ensino Formal: Estudos Publicados em } \\
\text { Revistas Acadêmicas Brasileiras. Patrícia de Lourdes Viegas; Zysman Neiman, v. 10, n. 2, } \\
2015 .\end{array}$ \\
\hline [Ref.9] & $\begin{array}{l}\text { Caminhos e dilemas da educação ambiental no contexto escolar. Maria Inêz Oliveira Araú- } \\
\text { jo; Mônica Andrade Modesto; Tatiana Ferreira Santos, v. 11, n. 2, 2016. }\end{array}$ \\
\hline [Ref.10] & $\begin{array}{l}\text { Convergências na Ecologia Política: quando a Educação Ambiental abraça a Luta por Justi- } \\
\text { ça Ambiental. Philippe Pomier Layrargues; Cleonice Puggian, v. 11, n. 2, 2016. }\end{array}$ \\
\hline [Ref.11] & $\begin{array}{l}\text { Educação Ambiental no ensino formal: Atuação do professor nas escolas municipais de } \\
\text { Cruz Das Almas - BA. Vanessa Ribeiro dos Reis; Girlene Santos de Souza; Viviane Borges } \\
\text { Dias, v. 11, n. 1, 2016. }\end{array}$ \\
\hline $\begin{array}{l}\text { Contribuições de uma Experiência Pedagógica em Educação Ambiental. Maria Socorro } \\
\text { Duarte da Silva Couto; Cláudia Sampaio Guimarães; Marlei de Fátima Pereira, v. 12, n. 1, } \\
\text { 2017. }\end{array}$ \\
\hline [Ref.13] & $\begin{array}{l}\text { Projeto de Educação Ambiental no Ensino Fundamental: Bases para práticas pedagógicas. } \\
\text { Maria de Fátima Barrozo Costa; Solange Castellano Fernandes Monteiro; Marco Antonio } \\
\text { Ferreira Costa, v. 21, 2013. }\end{array}$ \\
\hline
\end{tabular}

\subsection{Brief Description of the Articles}

The researchers formulated a university curriculum, and with the participation of a multidisciplinary team have developed a biannual course that is offered to undergraduate students aiming at literacy in Geosciences and then engaging them in complexity issues.

In an approach to socio-environmental problems, the article "How the emphasis on socio-scientific issues can influence student attitudes about science, its sustainability relevance and inter- pretations?” (Pelch e McConnell, 2017) [Ref.3] mentions the creation of a sustainability seminar for the first year of high school, which involved four subjects and relied on reflective, collaborative and experiential activities. The evaluation was carried out through a qualitative review of the posts in a blog of 18 participating students on which they were able to deepen complex issues of sustainability and recognize the challenge of consumerism.

The article "The Geology and Sociology of

\begin{tabular}{c|c|c|c|c|c}
\hline (C) Terrae Didat. & Campinas, SP & v.14 & n.3 & $304-312$ & jul./set. 2018 \\
\hline
\end{tabular}


consumerism: Teach Sustainability at a First Year Interdisciplinary Seminar “ (Walsh e Davis, 2017) [Ref.4] exposes the importance of scientific literacy, stating that educational systems must provide and invest on this proposal. The authors sought to determine whether exposure to socio-scientific issues using the subjects of Integrate course would result in positive changes in student attitudes in relation to science and its relevance. The work resulted in an inventory of students' attitudes that contributed to the perception of the relevance of scientific studies.

The periodic Enseñanza de las Ciencias: the article presents the characterization and analysis of teachers' perceptions and the identification of tendencies about environmental education, conceptions of the environment and complexity.

The article entitled: "Conceptions of Environmental Education and Professional Development of experimental science teachers in formation" (Cardona Restrepo, 2013) [Ref.5], consists of a case study that aims to identify and describe didactic knowledge and beliefs about EE in a group of science beginner teachers. Starting from the critical interpretative and dialectical paradigm, the author developed a three-semester course at the University of Antioquia in Colombia, that had the support of master teachers to analyze the depth of productions through questionnaires, written documents and interviews. The result showed that the professionals were able to cope better with the didactic-pedagogical challenges and improved their performance in classes.

Subirà \& Gargallo (2014) [Ref.6] carried out the identification and characterization of environmental conceptions in a group of EE professionals, having as theoretical basis the characterization of EE currents of L.Sauvè $(2004,2010)$. The work identified the standards of the professionals according to their conceptions of environment taking as reference the degree of complexity that reflects on the educational actions. Six conceptions of environment were detected according to the results of the research: connection, openness of scope, complexity, dimension and cultural transcendence, and politics.

The article "Characterization of the conceptions of complexity of a group of environmental education researchers" Subirà e Martinez (2017) [Ref.7] is based on the hypothesis that EE, as a discipline, evolves and incorporates complexity into an ontological and epistemological perspective. The study looks for the possible procedures and categories specific to an EE that assumes complexity as a paradigm, proposing an instrument of analysis to identify and characterize the conceptions of complexity of 93 participants of different formations in three formative sessions.

The study looks for possible procedures and categories in EE that assumes complexity as paradigm, proposing an analysis instrument to identify and characterize the conceptions of complexity for the 93 participants with different formation in three training sessions. According to the study, the incorporation of complexity into EE needs to evolve, requiring a standardization of procedures and languages within the research community.

In the Periodic Research in Environmental Education, the articles present review of publications in EE, reflection on the concepts of $\mathrm{EE}$ and its insertion in schools, analysis, description and evaluation of pedagogical practices in formal education.

The article: "The Practice of Environmental Education in the Field of Formal Education: Studies Published in Brazilian Academic Journals" (Viegas e Neiman, 2015) [Ref.8] presents the description and characterization of pedagogical practices of EE developed in the formal education in schools of the south-east of the country published between 2007 and 2012 in academic journals. The work does a survey of the subjects, disciplines involved through transversal or interdisciplinary projects strategies and techniques, processes of evaluation and characterization of environmental concepts. The research has a mapping profile, but it is not considered as "state of the art", it does not have as purpose the critical analysis of the pedagogical practices, but rather, the characterization and cataloging of the practices present in the scientific articles. It discusses the construction of several EE concepts and approaches, stating that they differ in the way and the manners of building the educational process, with flaws, gaps and dubious generalizations.

The article: "Paths and Dilemmas of Environmental Education in the School Context" (Araújo et al. 2016) [Ref.9] presents the issues listed in the Research and Discussion Group (Grupo de Pesquisa e Discussão - GPD) of EE in the School Context of the VIII Meeting of Environmental Researchers (VIII Encontro de Pesquisadores Ambientais - EPEA, 2015), reflecting on what was raised and pointing forward to future EE contributions. The GDP star- 
ted the discussion on the Decade of Education for Sustainable Development and involved topics such as: theoretical-methodological aspects, curriculum, public policies, teacher training, critical EE and school programs. Group discussions about issues related to the problems and challenges of teacher education, the need to open ways for EE and the role of critical $\mathrm{EE}$ in school programs in order to overcome the dichotomous vision and the naive, punctual and isolated practices that do not contribute to students thinking. Finally, the authors point out the new directions of the research in Environmental Education and the need for the EE, in the school context, to go beyond the walls of the school.

The article: "Convergences in Political Ecology: When Environmental Education embraces the Fight for Environmental Justice" (Layrargues e Puggian, 2016) [Ref.10] presented the reports about the systematization of the activities and results in the GPD (Research Discussion Group) in Environmental Education, Social Movements and Environmental Justice in VIII EPEA 2015. The article describes and analyzes the approved works, based on a critical EE for the construction and refinement of narratives that defend the effective articulation between $\mathrm{EE}$ and environmental justice as an exercise of pedagogical practices that involve educational mediation in cases of environmental conflict. The work points to a scenario of class struggle facing a political clash that aims to overcome the capitalist logic, in which community livelihoods and production are threatened with extinction.

Reis et al. (2016) in the article: "Environmental Education in Formal Education: Teachers' performance in municipal schools in Cruz das Almas - town in Bahia - Brazil" [Ref.11] analyze the teaching practice in EE in the disciplines of Elementary School in 2014. It involves a case study whose objective is to relate the teaching practices of EE with the National Curricular Parameters; to identify the possible difficulties presented by teachers on the subject EE and the interdisciplinarity. The authors point out the importance of this kind of research to contribute with teacher's work and the the effective insertion of interdisciplinarity as a promoter of citizenship and of the transformation of the basic education in the municipality which were principles indicated by The National Program of Environmental Education (Programa Nacional de Educação Ambiental (PNEA).

The article: "Contributions of a Pedagogical Experience in Environmental Education" (Couto;
Guimarães e Pereira, 2017) [Ref.12] verifies the necessary elements to pedagogical practice in $\mathrm{EE}$, contemplating the interdisciplinarity through three proposals that consider the construction, discussion and evaluation. The study was carried out in municipal schools in the years of 2013 and 2014, with teachers and Elementary School students, through planning, application of and EE proposal and its insertion in the Political-Pedagogical Project of school through the holding of an Environment Assembly, a Fair of Science and Environmental Development Projects. The authors presented experiences and discussions about proposals that start from the concept of sustainability as the guiding axis to attract the school community to the spaces of discussion, planning and application of these proposals in school. According to the authors, the insertion of EE through the investigation triggered a deep interaction in the school community, with a view to implementing interdisciplinarity in school. The discussion of the research points to the need for greater dialogue between disciplines, from the discussion of planning to execution of actions and the insertion of EE into School Political-Pedagogical Projects through interdiciplinary projects built collectively.

In the periodical REMEA an article was found that starts from the analysis and characterization of transversal projects in formal education, based on official documents such as the National Curricular Parameters (PCN) and the National Environmental Education Program (PNEA). The article: "Environmental Education Project in Elementary School: Bases for pedagogical practices" (Costa; Monteiro e F. Costa, 2013) [Ref.13] analyzes the content of $2 \mathrm{EE}$ project proposals in two schools in Rio de Janeiro. With the descriptive and qualitative method, were elaborated in the years 2005 to 2007, interviews and semi-structured questionnaires applied to teachers and students in order to obtain the perceptions about the projects and pedagogical practices in EE. The research involved 50 students in the eighth grade of Elementary School and 4 science teachers. The research revealed that such projects do not prioritize and do not adequately incorporate the EA proposals foreseen in NCPs. Attention, however, to the need for a more reflexive posture, in the sense of articulating the understanding about education and the environment to develop pedagogical practices that take into accouny the criativity, the participation of several people to participate, and the transformation of school space. 


\section{Analysis and Discussion of Results}

After this brief summary of the selected articles, we will make some comments on the tendencies of these articles in relation to School Level study focus, Thematic Area, Methodological Approach and Macrotendency of EE, trying to identify which of them are closer to our focus of study.

In relation to the School Level study focus we observed that five articles dealt with Elementary School [Ref. 8; 9; 11; 12; 13] and four dealt with High School, or equivalent [Ref.3; 4; 8; 9] with two of these studies dealing simultaneously with the two levels [Ref.8; 9]. Two papers focused their analysis on primary and secondary school teachers [Ref, 1;5], a work was targeted at Higher Education students [Ref.2] and one paper addressed the general educational context without addressing a specific level [Ref.10]. Two papers focus their analyzes to researchers in the area of Environmental Education [Ref.6;7]. Therefore, in relation to the School Level, five works have come closer to our main subject which are the works directed to Elementary School [Ref.8; 9; 11; 12; 13].

Relation to the Thematic Area, nine papers were explicitly addressed to Environmental Education [Ref. 5; 6; 7; 8; 9; 10;11;12;13]. The other works, although they did not explicitly mention EE, were initially considered to address issues compatible with Environmental Education. This is the case of the four works about geosciences, which addressed topics of geology focusing on the issue of sustainability [Ref. $1 ; 2 ; 3 ; 4]$.

Related to Methodological Approach, three works analyzed Pedagogical practices in Environmental Education [Ref. 11; 12; 13]; two works discussed about issues raised in EPEA Research and Discussion Groups [Ref.9; 10], and one of them [Ref.9] also discussed the pedagogical practices of EE in the school context; two articles surveyed the conceptions of researchers about environment and complexity [Ref. 6; 7]; Two papers have created the Seminar on Sustainability [Ref.3; 4]; a paper surveyed articles about pedagogical practices in academic journals [Ref.8]; a paper compiled approaches and teaching materials on Sustainability Ethics [Ref.1]; a paper proposed the formulation of a university curriculum that starts from the concept of Critical Zone of Earth to reach the final concept of environmental sustainability [Ref.2]; and an article developed a training course for teachers seeking to identify and describe the didactic knowledge and beliefs of science teachers about EE, discussing the professional development of these teachers [Ref.5]. The works on pedagogical practices [Ref.8; 9; 11; $12 ; 13]$ are more related to our research.

In relation to the macro trends of Environmental Education pointed out by Layrargues and Lima (2014) we observed that nine of the thirteen articles approached the Pragmatic macrotendency [Ref.1; 2; 3; 4; 5; 8; 11;12;13] which, according to the authors, is one in which the practices are aligned with Education for Sustainable Development and the idea of Sustainable Consumption. According to Layrargues and Lima (2014) this macro-tendency is related to a dynamic conservatism based on superficial and behavioral changes. In the case of the articles analyzed, although they have made interesting proposals, such as the development of differentiated curricula, interdisciplinary seminars, preparation of teacher training courses, among others, the proposals, according to the framework adopted here, did not include questions of economic, political and social nature that favored the problematization of the contradictions of development models and of society.

Two papers [Ref.6; 7] analyzed conceptions of EE researchers based on referential which highlight the importance of Environmental Education be discussed from the paradigm of complexity, approaching Critical Environmental Education, which, according to Layrargues and Lima (2014, p.33) "Tends to combine with the thought of complexity when realizing that contemporary issues, such as the environmental question, do not find answers in reductionist solutions." The authors also highlighted the potential of complexity to re-signify false dualities inserted by the Cartesian paradigm in the relationships between individual and society, knowledge and power, nature and culture, among others.

Two papers [Ref.9; 10] discussed issues raised in the EPEA Research and Discussion Groups. One [Ref.9] presents the discussions about the paths and dilemmas of Environmental Education in the school context and starts punctuating its work in the scope of Education for Sustainable Development. It discusses the research presented in the EPEA on EE in the school context, about the ways and difficulties encountered by teachers in the development of their pedagogical practices, seeking to evaluate the developments of the Decade for Sustainable Development, which would characterize it in the Pragmatic Macrotendency (Layrargues and Lima, 
2014). However, with the analysis of the papers presented at the event, the authors identified that the most cited authors in the work on EE in the school context are aligned to the macro-tendency of Critical Environmental Education, highlighting the importance of this strand. Therefore, this work can characterize a transition between the pragmatic and critical macro trends, or, then, reveal the distance between what is produced in the context of academic conferences (Critique) and the reality of the school context (Pragmatics).

Finally, the work of Ref. 10 aligns with the Macrotrendency of Critical EE, because it is part of EE's critical references to discuss issues raised in the EPEA's GPD, on the articulation between $\mathrm{EE}$ and environmental justice. According to the authors, all the works on the line "Environmental Education, Social Movements and Environmental Justice of the VIII EPEA (2015) evidenced a strong ideological adherence to the Critical macro-trend of Environmental Education. The authors also emphasize the distinction that demarcates the educative intentionality of critical EE:

Contrary to the expected contribution of education to the reversal of the environmental crisis, it is not enough to look at the future and to wish to build a sustainable society with individuals who are ecologically aware of what they need to do in terms of a sustainable life, without, at the same time, one understands the structuring dimension of how the present economic model works and its mechanisms that have led us to this situation of socio-environmental degradation that affects, differentially, social groups, to finally act concretely on this dimension of reality. (Layrargues and Puggian, 2016, p.78).

From the reading of the articles we could see the predominance of the pragmatic macrotendency, understood by Layrargues and Lima (2014, p 30) as "an expression of the environmentalism of results, the contemporary pragmatism and the market ecologism stemming from the neoliberal hegemony established worldwide since the 1980s." On the other hand, articles from Environmental Education Research Meetings have shown that the Critical Macrotendency has been gaining more and more space in the Brazilian academic environment.

According to Layrargues e Lima (2014), in the critical macrotendency, the Environmental Education is conected to political and social debate with the population and seeks to problematize the contradictions of the development model of society, enabling the emancipation and transformation of the reality in which we live.

Regarding the journals consulted, we observed that the four articles in the Journal of Geoscience Education [Ref.1; 2; 3; 4] presented compilation of materials, curriculum formulation, and creation of seminars for teachers or students of Higher Education and High School, based on the concept of environmental sustainability. Therefore, these articles have less relation with our research in terms of school level; EE methodological approach and macrotendencies.

The three articles of Revista Enseñanza de las Ciencias [Ref.5; 6; 7] carry out a teacher training course and characterization and analysis of researchers' perceptions and tendencies about Environmental Education, environment and complexity, as well as their insertion in formal education through pedagogical projects and practices, presenting valuable contributions in relation to the importance of reflection for the incorporation of the concepts of complexity and interdisciplinarity. Therefore, although these articles have less relation with our research in terms of school level and methodological approach, they point to the importance of the identification and characterization of the concepts of complexity and environment, the implementation of interdisciplinarity in teacher training, EE practices in schools and also for the need to deepen the research and discussions about complexity, as well as to signal a possible transition between the Pragmatic and Critical Macrotendencies.

From the Periodic Pesquisa em Educação Ambiental 5 articles were obtained [Ref.8; 9; 10; $11 ; 12]$ who have reviewed EE publications in academic journals, reflexion about Grupos de Pesquisa e Discussão (GPD - Groups of Research and Discussion) of EP EE, and analysis, description and evaluation of EE pedagogical practices in formal education These studies showed a greater relationship with our research in terms of school level [Ref.8; 9; 11; 12], methodological approach [Ref. 11, 12] and EE macro-tendency [Ref.10].

In the journal REMEA an article [Ref.13] was found that analyzes and characterizes the pedagogical projects developed in EE in two schools. This study presented a greater relation with our research, in relation to the school level study focus and and the methodological approach, since it deals with the characterization of Environmental Education projects and pedagogical practices in Elementary 
School. Although it does not explicitly align with the Critical Macrotendency, it highlights important issues compatible with this macrotrendency such as the importance of solving local problems and the insertion of interdisciplinarity and complexity in $\mathrm{EE}$ projects.

Therefore, among the thirteen articles identified in the periodicals selected in the period corresponding to the last five years (2013-2017), we found five that had some relation with our research [Ref.8; 9; 11; 12; 13], as previously described. Although none of these articles are explicitly related to our specific study focus (academic data collection on pedagogical practices in Environmental Education developed by Government Organizations), they have provided important clues and reflections that contributed to the continuity of the research.

\section{Final considerations}

The bibliographic review plays an important role in academic works, because through it, we have been able to situate research in the great area of study and to contextualize it. Fracalanza et al (2005) considers that this type of work helps in the analysis of the trajectory, trends, gaps and controversies in the area and supports other research in this field from the constitution of a bibliographic collection, which will simplify the work of other researchers, teachers and anybody else interested in studying EE.

From a careful selection, we were able to identify papers in national and international scientific journals that presented some points in common with our research. However, it was observed that in this first survey there were no studies that dealt specifically with the focus of our master's research: academic data collection on pedagogical practices in Environmental Education in Primary Education developed by Governmental Organizations, which justifies its development.

Proceeding our studies, we will to make a survey of theses and dissertations on this subject and develop a characterization and critical analysis of the trends of EE on pedagogical practices in schools. With this study we will try to point out ways to reduce the chasm, as pointed out by Bagnolo (2010) existing between academic production and school practices so that they can effectively reflect the advances and consolidation of EE.

Thus, we highlight the importance of biblio- graphic review works for the dissemination of knowledge production on pedagogical practices of Environmental Education, also contributing to the organization of a theoretical and practical framework to guide the pedagogical proposals in $\mathrm{EE}$ as well as in the development of new studies aiming at the improvement of teaching, a purpose that inspired the present work.

\section{Bibliographic References}

Amaral I.A. 2003. Oficinas de produção em ensino de Ciências: uma proposta metodológica de formação continuada de professores. In: Tiballi E.F.A., Chaves S M. 2003. Concepções e práticas em formação de professores. Rio de Janeiro: DP\&A.

Bagnolo C.M. 2010. Educação Ambiental: a teoria, a prática e a universidade. Ciências em Foco, 1(3):0107.

Brügger P. 1994. Educação ou adestramento ambiental? Santa Catarina: Letras Contemporâneas.

Carvalho L.M.de, Tomazello M.G.C., Oliveira H.T. 2009. Pesquisa em Educação Ambiental: panorama da produção brasileira e alguns de seus dilemas. Cad. CEDES, 29(77):13-27.

Fracalanza H., Amaral I.A.do, Megid Neto J.M., Eberlin T.S. 2005. A educação ambiental no Brasil. Panorama inicial da produção acadêmica. In: Encontro Nacional de Pesquisa em Educação em Ciências, , 5, Brasil2005. Atas... ENPEC

Layrargues P. P., Lima G. 2014. As macrotendências político-pedagógicas da educação ambiental brasileira. Ambiente \& Sociedade [Online], 17(1):23-40.

Leff E. 2012. Saber ambiental: sustentabilidade, racionalidade, complexidade, poder. 9. ed. Rio de Janeiro: Vozes.

Lima G. F. C. 2005. Formação e dinâmica do campo da educação ambiental no Brasil: emergência, identidades e desafios. Tese (Doutorado em Ciências Sociais) Instituto de Filosofia e Ciências Humanas, Unicamp, Campinas, SP.

Megid Neto J. 1999. Tendências da pesquisa acadêmica sobre o ensino de Ciências no Nível Fundamental. Tese (Doutorado em Educação) - Faculdade de Educação, Unicamp, Campinas, SP.

Megid Neto J. 2009. Educação ambiental como campo de conhecimento: a contribuição das pesquisas acadêmicas para sua consolidação no Brasil. Pesquisa em Educação Ambiental, 4(2):95-110.

Rink J. 2009. Análise da Produção Acadêmica Apresentada nos encontros de Pesquisa em Educação Ambiental (EPEA). Campinas, Fac. Educ., Unicamp. (Dissert. Mestr. Educação)

Silva M S. 2013. Conceitos e Críticas ao Termo Sustentabilidade em Lenzi. Gaia Scientia, 7(1): 114118.

Sposito M.P. coord. 2001. Juventude e escolarização (19801998). Brasília: MEC, Inep, Comped. (Série Estado do Conhecimento, n.7).

\begin{tabular}{c|c|c|c|c|c}
\hline C Terrae Didat. & Campinas, SP & v.14 & n.3 & 304-312 & jul./set. 2018 \\
\hline
\end{tabular}

